\title{
OPPORTUNITIES FOR SUSTAINABLE DEVELOPMENT OF RURAL TOURISM IN THE MUNICIPALITY OF VRBAS
}

\author{
Milutin Mrkša ${ }^{1}$, Tamara Gajič
}

\section{Summary}

Rural tourism is the tourism development in rural areas. Under the rural tourism means all tourism activities that take place in rural areas that require travel services in the same places. Therefore in order to develop rural tourism is necessary to create an offer that includes the involvement of the local population, to preserve the environment in the tourist areas and enable economic gain. All of the above suggests that this approach can talk about sustainable development of rural tourism. The paper presents Vrbas municipality and potential drawbacks for the development of sustainable rural tourism and proposed concrete measures.

Key words: Rural tourism, environment, sustainable development.

JEL: $Q 16, M 24$

\section{Introduction}

At the beginning of the work it is necessary to look at the definition of sustainable development, rural development and rural tourism, as well as the basic principles of design and context of the proposed measures in further writing work.

The concept of sustainable development has become the guiding principle of development policies in a growing number of organizations, from local to national levels. The roots of today's forms of sustainable development dating back to the values of people that are nonrenewable natural resources, there is a lot of negative human impacts on the environment and the need to define and adopt a development direction that will ensure their principles or combine three elements: economic, social and environmental and to the mutual relations of these elements, with the obligatory respect and combination, be progressive, but not right now and the future.

1 Milutin M. Mrkša, Ph.D., Higher School of Professional Business Studies, Vladimira Perica Valtera no. 4, 21000 Novi Sad, Serbia, Phone: +381 63295 711, E-mail: mmrksa@gmail.com

2 Tamara Gajić, Ph.D., Higher School of Professional Business Studies, Vladimira Perica Valtera no. 4, 21000 Novi Sad, Serbia, Phone: +381 2148540 16, E-mail: gajic tamara@yahoo.com

EP 2014 (61) 1 (163-175) 
A conceptual model of sustainable development was seen as a consensus of human, social, economic, technological, cultural development and conservation, rehabilitation and improvement of the environment and protection of the natural heritage and the initial native ecosystems. Balancing all sides of human life should ensure human well-being (Cobb, 1995). It is this definition of sustainable development can be the basis for defining sustainable rural development. The current rural development policy that is applied in the European Union pursued our state, defined in Agenda 2000 and is based on the principle of multi-functionality of agriculture, multi-sectors and integrated approach to the rural economy, diversification of activities, creating new sources of income in rural areas, employment opportunities, protection of rural resources, decentralization, partnership at local and regional level and transparency in creating and managing development programs (Stojanović, Manić, 2009). The World Tourism Organization (WTO) has characterized the response of tourism as a peak in the management of all resources in such a way that economic, social and esthetic needs can be fulfilled while maintaining cultural integrity, essential ecological processes and biological diversity and the maintenance systems of the living world is a new and higher quality set of rules and principles in the development of tourism (Radulović et al., 1997).

Rural tourism is bound and takes place in rural areas, in this case in the rural areas of the municipality of Vrbas. However, rural tourism is not only a holiday in the country, as it basically looks, but a wide range of activities in rural areas. Mainly as tourist activities related to natural and anthropogenic conditions, as in the case of rural areas over a ten tourist activities, eco, sport and recreation, culture, health, sailing, hunting, fishing, educational, religious, etc.

With regard to the specific topic of which is linked to the rural parts of the Municipalities of Vrbas and sustainable development of rural tourism in the same, it is necessary to pay special attention to integral parts of sustainability. The economic part is reflected in the involvement of the local population in the creation of rural tourism product through the provision of accommodation services, marketing of agricultural products, marketing of food and non food products of domestic industries and the creation of conditions for additional income. The social component is reflected in improving the quality of life in rural areas through the rehabilitation and construction of infrastructure, and raising the level of awareness and knowledge, creating an environment for young people to stay in rural areas and strengthen rural communities. Protection of the environment as the third part of sustainability is to be constantly present in the panes and development activities as a factor that should not be compromised and neglected, that is, to define the time and respect ecological capacity and the impact on the environment.

\section{General characteristics of the municipality of Vrbas}

Vrbas is crossing the central and southern Backa along the route of the Great Backa canal, which forms the backbone of a hydro system Danube-Tisa-Danube Canal. While as the centre of the Vrbas municipality has a central position in relation to the back, other settlements are more inclined towards its southern part. In addition to the Vrbas, which is also the center of the municipality, the municipality of Vrbas consists of the 
following settlements: Bačko Dobro Polje, Zmajevo, Kucura, Ravno Selo and Savino Selo (Miljković et al., 1998).

Vrbas municipality covers an area of two geomorphic units: the loess plateau and loess terrace. These units, although relief is clearly defined as distinct morphological categories have many common features. Height difference between them is not the same everywhere. Most notably in the border area to the tower, where the loess plateau dominating the loess terrace within height of $17 \mathrm{~m}$. Southeast of the Vrbas River that border is less pronounced because the transition from one form to another in the form of gentle slopes. The total dissection of the relief is $24 \mathrm{~m}$ and ranges from $80 \mathrm{~m}$ to 104 $\mathrm{m}$ above sea level. Meadow calcareous chernozem soil is most common in the area of the municipality of Vrbas (Miljković et al., 1998). This is the most common types of soil on loess terrace. The average thickness of the humus horizon of this soil type is $65-70 \mathrm{~cm}$. Meadow calcareous black soil has good structure, water-physical and chemical properties, in particular, is rich in nitrogen, phosphorus and potassium, and an agricultural land of high productive value. Chernozem on loess plateau, meadow black soil is relatively deep humus horizon, very favourable and stable structure loamy texture, is well supplied with plant nutrients in available form, water is good physical and thermal properties. Good physical and chemical properties of the deeper layers of the basic characteristics of production for which it is classified as a land of high productive capacity. Carbonate chernozem - extends also to the loess terrace and the loess plateau. On the loess terrace carbonate chernozem is present in several locations, while the loess plateaus of southern parts of the project. The average thickness of the humus horizon is $40-70 \mathrm{~cm}$. Colour is brown calcareous chernozem-brown on the loess plateau, while the loess terrace brownish-black. Solonchak a type of salty soil. It is a type of brine created during salinization. In the municipality there is a small territory solonchak. This salty soil can be successfully unsalted lowering of groundwater levels (Mrkša, Milanović, 2012).

Clime has no pronounced specificity compared to other parts of Vojvodina, and has features continental steppe climate. Annual average air temperature is around $11^{\circ} \mathrm{C}$ and annual average rainfall is $560 \mathrm{~mm}$. The value of insolation is about $2003 \mathrm{~h}$ per year, while the cloudiness is about $60 \%$ per year (Popović et al., 2011). For much of the territory is most frequent north-westerly wind in the summer and spring, while the intensity somewhat weaker southeast wind-wind, which is most frequent in autumn and winter.

The most important hydro graphic facility in the territory of the Grand Backa Canal, but no less important and other channels hydro system Danube-Tisa-Danube Canal. Digging of the canal has greatly contributed to the creation of the Vrbas as a strong industrial centre, because the channel was designed primarily for transportation. However, the major waterway channel has today become a major environmental problem Vrbas, because he used the same industry, and still used for wastewater discharge. In addition to DTD hydro system, through the municipality, river flows Jegricka, which is partly protected as a nature park category III. The importance of groundwater, except for EP 2014 (61) 1 (163-175) 
water, is reflected in the existence of three thermal spring waters that are both energy and health resort potential (Mrkša, Gajić, 2013).

Flora and fauna are directly related to the geomorphologic, soil, climate, hydrological and anthropogenic factors, so that in the community, depending on the type of land, more land - drier and lower, wetter (marsh), and develop adequate wildlife. Forests to a significant extent do not exist, except for some trees near the banks of the canal Jegricka, mostly poplar, black locust and pine. With the roads are chaparral and shrub, while at the site Carnok, a significant number of protected species. The most numerous faunistic groups are over 100 bird species, then fish with more than 20 species, while in the hunting and the domains may encounter deer, rabbit, pheasant, quail and others.

\section{Catering facilities}

Catering in the Vrbas municipality is most prevalent in Vrbas, where there is more than $60 \%$ of restaurants. Most of the buildings are privately owned. The offer includes all types of extensions: snack bars, cafes, coffee shops, pizzerias, pastry and dairy restaurants.

Table 1. Number of seats in restaurants and ownership structure

\begin{tabular}{|l|l|c|c|c|}
\hline \multirow{2}{*}{ Place } & \multirow{2}{*}{ Object } & \multicolumn{2}{c|}{ Number of seats } & \multirow{2}{*}{ Ownership } \\
\cline { 3 - 4 } & & Closed part & Terrace / Garden & \\
\hline Kucura & Backi rucak & 66 & $/$ & Privately \\
\hline Backo Dobro Polje & Durmitor & 250 & 100 & Privately \\
\hline Backo Dobro Polje & Braća Mandic & 80 & 50 & Privately \\
\hline Zmajevo & Obilic & 80 & $/$ & National \\
\hline Zmajevo & Jezero & 72 & 16 & Privately \\
\hline
\end{tabular}

Source: According authors research.

Brothers Madnic Motel is located on the E-75, in the direction of Novi Sad. It was built in 1994. years, with 6 single rooms, 24 double rooms and 4 suites. Each room has a bathroom, air conditioning, TV and internet. The motel has a restaurant within which it operates banquet hall, a breakfast room, a gallery with a coffee bar and a terrace. The complex includes a gas station and fast food restaurant with a cocktail bar. Ethno house Misljenka in Zmejevo has four double bungalows and a small restaurant. Zodiac Motel in Savino Selo is closed. Check-In addition to the facility, which is not in an enviable situation (needs renovation) complex, has 10ha of land that could be used to build additional facilities. The total volume of tourist traffic and capacity utilization in the municipality is very small compared to the real possibilities of tourism. It should be noted that the scope and level of use of accommodation facilities is only an indicator, not an indicator of tourist spending a certain location or tourist places. What is the tourist offer of a higher quality and more diverse and overall travel spending is comparatively higher. 
Table 2. Tourist arrivals and overnight stays in the municipality of Vrbas, in the period 2005-2010.

\begin{tabular}{|r|r|r|r|r|r|r|}
\hline \multirow{2}{*}{ Year } & \multicolumn{3}{|c|}{ Tourists } & \multicolumn{3}{|c|}{ Tourist nights } \\
\cline { 2 - 7 } & \multicolumn{1}{|c|}{ T } & \multicolumn{1}{|c|}{ D } & F & \multicolumn{1}{c|}{ T } & \multicolumn{1}{c|}{ D } \\
\hline 2005 & 5.086 & 4.188 & 898 & 14.593 & 12.518 & 2.075 \\
\hline 2006 & 9.304 & 5.346 & 3.958 & 22.055 & 17.787 & 4.268 \\
\hline 2007 & 10.186 & 4.445 & 5.741 & 19.354 & 12.457 & 6.897 \\
\hline 2008 & 12.415 & 7.900 & 4.515 & 17.635 & 12.054 & 5.581 \\
\hline 2009 & 7.520 & 5.555 & 1.665 & 11.226 & 8.770 & 2.456 \\
\hline 2010 & 8.543 & 6740 & 1.803 & 13.960 & 10.938 & 3.022 \\
\hline
\end{tabular}

Source: Municipalities in Serbia, publications for selected years (2006-2011), Statistical Office of the Republic of Serbia, Belgrade, Serbia.

\section{Possible forms of tourism activities in rural areas of the municipality}

In rural areas of the municipality of Vrbas are potentials and capacities for the development of the following tourism activities: ecotourism, cultural tourism, hunting and fishing, sports and recreation. These four forms of tourism activities were selected because of their development of a realistic opportunity for the evaluations of which do not need special investments. It may be noted that their development conditions for the development of tourism and other activities that require significant financial investment. Development of these tourism activities animate the local population to determine the provision of housing in rural households, to start by having only one room and rearrange issued, depending on the volume of guests later expanded capacity.

Ecotourism is a form of tourism upsurge which is projected to soon be, if not, the dominant trend of tourism development at a global level. The planning of ecotourism must answer the questions: how to manage visitors, how to organize and edit eco destinations to preserve it and to tourists could experience feelings of closeness with nature and, at times, be integrated into the local community, to build tourist accommodation on the model criteria "ecolodge" (protection of natural and cultural values, minimal environmental impact and integration into the landscape, low water consumption, alternative energy sources and careful waste management, etc.) to existing and new hotels and make a commitment to doing business by respecting the principles of sustainability and environmental protection.

In the municipality of Vrbas should make a serious attempt (effort) to develop and implement a model of eco-tourism. As undoubtedly the main eco destinations plan spacious and uninhabited or sparsely populated parts of the region and protected areas. The main contents of their eco-visitors would be: a discrete network of marked walking trail excursion, with possible editing of individual sections of cycling; horse, accompanied by a local guide, or ride a horse-drawn carriage or other; educational and scientific activities, bird watching; picking mushrooms, medicinal plants and harvesting with a guide or host; observation or participation in the processing of milk and other traditional works in the authentic rural households; observation or 
participation in traditional arts, games and contests; lodging and stay in tents or in huts that are earmarked for the purpose built in traditional / authentic architectural style of the building. Potential eco destinations would be: Nature Park "Jegricka"; Natural Monument "Carnok"; Provalije; Zmajevacka lakes; Kosancic; Windmill in Ravno Selo; Motel Zodiac in Savino Selo; Unpolluted coast river canal.

Cultural tourism - the cultural tourism resources include various types of cultural heritage. The different classifications are usually distinguished: cultural and historical monuments, architectural objects, ethnographic complexes, monastery complexes and churches, museums and monuments, exhibitions, galleries and fairs, cultural forums, folk festivals and various cultural attractions. Cultural tourism attracts many tourists. According to studies of the European Commission 20\% of tourist arrivals in Europe corresponds to the cultural motivations of visitors, while $60 \%$ of European tourists are actively engaged in cultural discoveries and cultural tourism. Cultural tourism directly helps establish mutual respect among peoples through studying the history, preservation of historical, cultural and archaeological monuments.

The most significant cultural and historical monuments in the rural parts of the Vrbas municipality are Orthodox Church in the Zmajevo, the Orthodox Church in Ravno Selo, which houses two valuable religious books "Octoechos" Bozidar Vukovic and "Osmoglasnik" Jeronim Zagurović, Greek Catholic church in Kucura, founded in 1765th, the Roman Catholic Church in Kucura, built je1859. Year, Villa in Savino Selo was built in the late nineteenth century Hungarian Art Nouveau style. It was built as a family home then landowners who had a mill at the same place. Today, the villa is a separate clinic medical center. The building was restored a few years ago and is in excellent condition. Windmill in Ravno Selo owned by painter Vladimir Stepanov, built on the place of illegal dumping. Interior of the windmill has been converted into studio (ground floor) above the studio showroom that reflects the traditional life of the region, filled with hundreds of items (old furniture, rugs, miscellaneous utensils, old tools, etc.). The area around the windmill is filled with about a hundred species of conifers, more than 300 kinds of seasonal and multi-annual flowers and deciduous trees, about 80 species of bushy trees and ornamental shrubs. In the garden there is a small lake with cascades, fountains and a wooden bridge.

The most important tourist events that take place in urban areas of the municipality of Vrbas are Kostelnik an inter municipal fall musical and poetic manifestation meeting choirs organized by KDP "Karpati" and KC Vrbas, in November; Marigold Festival children's poets held in Savino Selo since 1989. The international character and excels in working with gifted children and writers, the festival is in its publishing activities established a special edition of the first book most talented poet or poetess; Art Colony "Triangl" in Savino Selo brings together many powerful and talented artists, in the traditional May, who three-day interval create their images, mostly of landscapes, still lives, associative and figuratively, author and aesthetically liberated; Kucura harvest an event at which the act Ruthenian and Ukrainian cultural clubs, and several companies of other ethnic communities Vojvodina, whose aim is to preserve and foster the folk 
heritage Russians and other ethnic groups; tamburitza music festival held in the Dragon in honor of Sava Vukosavljev one of the most prominent figures in the music scene in Vojvodina during the second half of the last century; "Fijakerijada" in Ravno Selo is a traditional equestrian events with a revue and competitive, the competitive part is demonstrated through the republican priority in teams, where the particular assess the look and grace of horses, horse-drawn carts and coachmen, held in August, and the organizer of the Jockey Club "Mustang" from the Ravno Selo.

Specifics of hunting and fishing apart from other forms of tourism trends are reflected in the motif and the extreme complementarily of these activities. The motive of hunting tourism is hunting wildlife whereas fishing tourism is catch fish. What is important to note that in addition to evaluation of wildlife as a natural resource, come up to their sales, as opposed to other types of tourist movement in which the natural resources of a framework for a tourist developments and to meet tourist needs. Hunting and fishing tourism activity is organized by the strict compliance with hunting and fishing and the professional, ethical and legal standards relating to the manner of enforcement of hunting and fishing. Hunting and fishing activities are clearly and precisely defined the duration of the hunting and fishing seasons and species of game or fish to which they relate. It is extremely important that standards are fully respected otherwise it could be a complete extinction of certain species of wild animals and fish (Mrksa, 2009).

Hunting Association "Vrbas" managing the hunting ground "Koviljak" the total area of 37.566 ha, of which hunting area is 33,835 ha. The association is composed of a hunting society "Pheasant" from Vrbas, "Hawk" from Kucura, "Pheasant" in Savino Selo, "Rabbit" from the Ravno Selo, "Deer" from the Zmajevo and the "Partridge" from Backa Dobro Polje with about 570 members. At work the next hunting facilities: 5 stable waiting 73 for feeding deer, 191 for feeding pheasants and partridges, 97 soloists, 21 watering hole, two shelters for pheasants. Constantly cultivated species of wildlife are deer, rabbit, pheasant and partridge Poland. Professional service has the gamekeeper employed full-time and 36 volunteer rangers. For hunting the most important is summer hunting quail, doves and turtledoves, and winter hunting ducks hang out-and-White-fronted geese.

The special significance of hunting lies in the fact that modern hunting is conceived and constituted so that it is in the function of sustainable development. It means that hunting which represents a complex activity of managing wildlife populations for their protection, breeding (artificial production, population, health care, nutrition), hunting and rational use, as well as maintaining and improving the habitat conditions in hunting grounds, not only provides the optimum reproducibility of the existing wildlife populations according to the potentials of their habitats (biological and economic capacity of a hunting ground), but also aims to prevent and repair any damage wildlife may cause in a given ecosystem or biotope (Prentovic et al., 2012). 
Graph 1. Model for Sustainable Rural Tourism

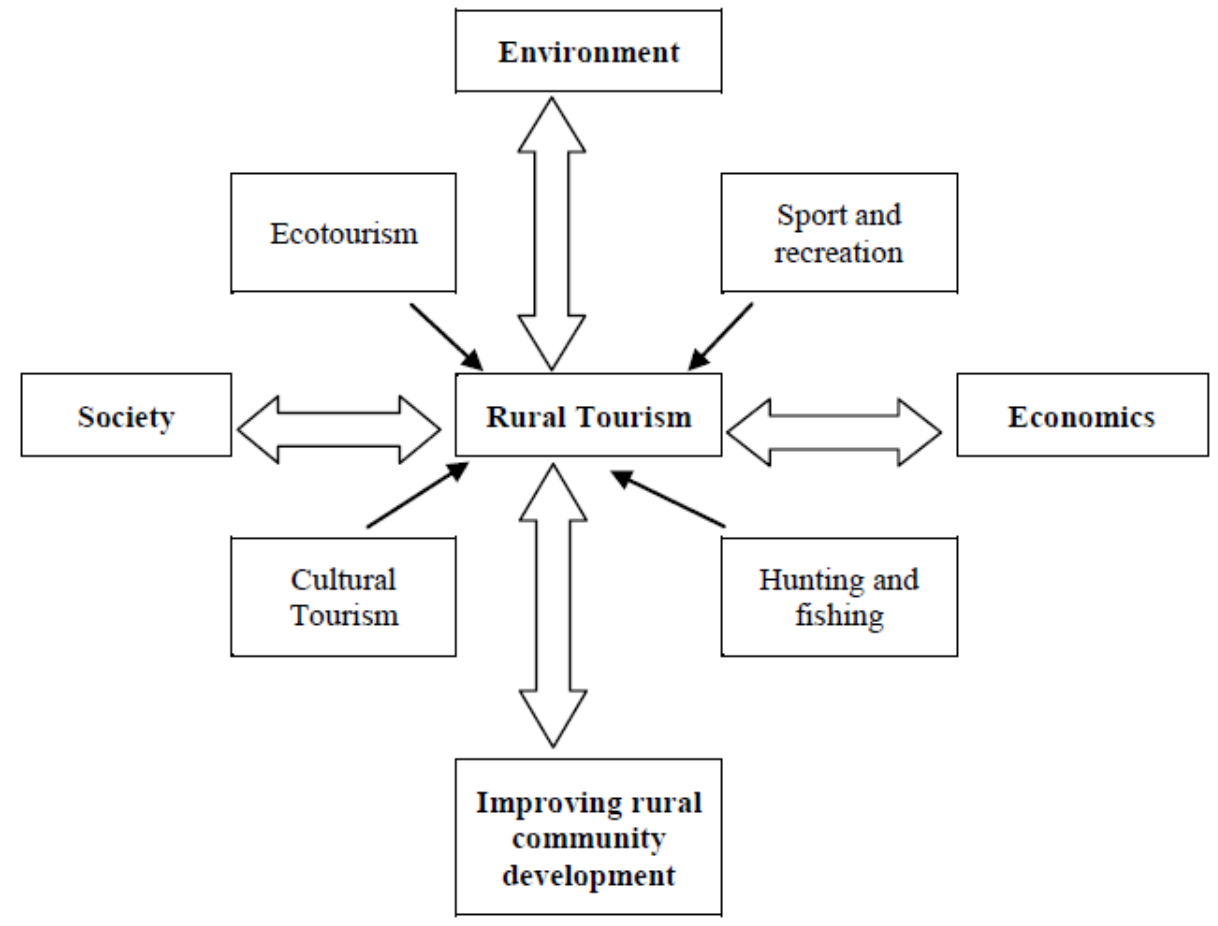

Source: Authors point of view.

The main task of the association is the preservation of fishing delegated control of surface waters and fish stocks. This is accomplished through the action of maintenance, stocking and storage of poachers and illegal means of fishing. Often, in accordance with the regulations and hunting seasons are organized competitions and sports fishing capital examples. In the municipality of Vrbas function following associations: "goldfish" from Vrbas, "Perch" from Kucura, "Jegricka" from Zmajevo and "carp" in Savino Selo. In addition to regular activities that include situation of sport fishing grounds, fish stocks, conservation and management of the same, organized the championship, league competitions, schools, fishing, etc. Important fishing events include "Stukijada" in Savino Selo, the Dragon's Children's camp - the school of carp fishing, "Carp Cup" on Zmajevačka Lakes and others.

Of sport and recreation touristic activities - the relationship between sport and tourism today is emerging as a mutually beneficial process, because it created an interactive relationship, and sport is shown as a separate part of the tourism industry, and more and more opportunities to enrich the tourist offer of the sport and support the development of sport through tourism. According to Plavsa (2007) sports activity is not the same for everyone, nor is her experience the same even for the same person at different ages, the specific importance of sport and tourism is the effect that leave of different people, or is person at different times of life. This type of tourism in recent times is growing 
in popularity and is of interest to a very different target groups, from children to the very elderly. The basis for mass organization and the dominance of this type of tourism in the destination represent natural conditions (suitable relief, climate, well-preserved environment, etc.) and a well-developed general infrastructure, facilities for adequate housing and facilities for sports and recreation. Population, it can be divided into two parts, one of which involves providing athletes with the desire to have as many elite athletes from a variety of disciplines and others, which involves the creation of content for the widest and most varied forms of recreation that is now common practice of people regardless of age, constitution, and even health.

In each of the settlements are an outdoor football field, tennis courts, football and handball. These two sports have the highest traditions of the region. The Flat Village's 2012th year built mini pitch, while that same court has existed for several years in the sport complex "Obilic" in Zmajevo, which still includes open fields for soccer, and indoor facility is a restaurant and a table tennis room. All outdoor handball courts and basketball courts are located within the primary school until the completion of the school room in all localities (except Kucura that already has a school sports hall) is expected in the 2013th year. In addition to these fields and facilities under construction, sports and leisure activities are possible and unpolluted rivers, of all the river channels DTD hydro system and Jegricka. In addition to bathing activities on the water as possible and boating and kayaking, while banks can arrange for beach volleyball, mini football, table tennis and others.

\section{Tourism and Environment}

In planning for the sustainable development of the environment as an integral part of sustainability is of great importance. The development of tourism in the context of sustainable rural development and need to be sustainable, which means that equal attention, should be paid to the relationship between tourism and the environment. Ecological capacity - the capacity or the capacity of the ecological environment is defined as "the ability of the environment to accept a certain amount of pollutants per unit of time and space so that no irreparable damage to the environment"3. In addition, it is necessary to quote the relevant terms and definitions relating to capacity, and that "the environment" - which is "a collection of natural and manmade resources whose complex interrelationships make the environment or the space and conditions for life" and "pollutants", that "the discharge of materials into the environment, affecting or may affect its natural composition, properties and integrity" (Mrksa, 2009).

International recommendations for policy and planning for sustainable tourism allocate 12 objectives related to economic viability, local prosperity, employment, social justice, meeting the needs of a lot of visitors, local management and organization, protection of cultural heritage, being of the community, the physical integrity of the landscape / space, biological diversity, wise use of resources and clean environment.

However, the successful implementation of sustainability implies the prior identification of indicators, which is a very large and complex task. Based on the experiences of other

3 Zakon o zaštiti životne sredine, Službeni glasnik Republike Srbije, br. 36/09.

EP 2014 (61) 1 (163-175) 
countries, it requires time consuming research ( 2 to 3 years), as the number of indicators used so far is a few hundred, based on five main criteria for selection. As in Serbia, at the level of institutions and bodies responsible for tourism such a study has not been done, it is also the objective limitation that in the terms and conditions of the financial, tourism sustainability indicators identified and applied to the case of the municipality of Vrbas.

An important issue is to identify the limits of development of tourism. Model / concept of "carrier / border capacity" for a long time the subject of debate in the academic world and its application to tourism suffered strong and justified criticism. For these reasons, this concept has been modified and it is entered in the realistic / pragmatic approach to the assessment of the sustainability of tourism increasingly used model "limits of acceptable change".

For the municipality of Vrbas, it can be said that the changes (impact) that brings tourism development acceptable if: not degrade or violates the aesthetics of the landscape, especially those parts of the areas where development is planned ecotourism; does not damage natural habitats and of wild fauna and flora through measures defined laws on the protection of these resources and values, and their protection under international agreements to which our country has acceded; does not condition / generate excessive and improper use of natural resources, especially water, plant life, wildlife, fish, outside the legal framework and the framework determined and verified programs grounds; does not generate waste and garbage in places and manner obviously a problem esthetic and hygienic-sanitary nature; does not create further pollution of air, water and soil through standards set by law and other regulations. Planned forms of tourism, construction and renovation of facilities and other works related to the development of rural tourism, the development of transport and other infrastructure, looking at the strategic level, not exceeding indicating the following conditions /criteria.

Ecological capacity of the municipality are certainly beyond the scope and types of changes that can be expected due to the planned development of tourism and the development of, for now, is limited by environmental restrictions for market, economic and socio-demographic conditions. Tourist use of space leads to significant anthropo ecosystems and space, which is divided into harmless involving very small load, the maximum allowed, dangerous, critical and catastrophic. The harmless pressures on the landscape and the ecosystem are when the natural system of irreversible changes doesn't occur. The effect of such natural complex load leads to the second or third level of digression. Load Level II are considered low if the natural compound capable of withstanding heavy burden not losing reproductive power. Maximum allowed travel pressure causes the natural complex is in the third category digression. If natural complex transition from III to IV category, beyond the limit of endurance, the load is considered dangerous. Criticality corresponds to level IV digression. Disastrous burden resulting ecosystem or natural landscape in the $\mathrm{V}$ stage digression in which the damaged natural connections among the natural components. Different types of natural complexes have their own specific structure and characteristics of the internal link between morphological units systems react differently to external impacts and within it the load of tourists. Because load is a natural complex safe, natural complex of the second type can be dangerous or critical. Established norms allowable loads are basic sizes that can extrapolate to all other types of natural complexes and, depending on their ecological characteristics and the planned 
areas for extended periods of rest (Ljesevic, 2003; Mrksa, 2009). According to the World Tourism Organization (WTO) has been proposed maximum load space tourists related to the different activities and recreational areas. Basic preventive measures for environmental protection and nature of adverse tourism activities and activities to determine the capacity of tourism activities and visits.

\section{Final considerations}

The main resources / resources for sustainable development of rural tourism in Vrbas are natural and human resources, while the main activities are agriculture and tourism. Combining and steady development and improvement of the above resources and activities can achieve the desired results. Based on the established natural and anthropogenic resources presented are the possible forms of tourism with the expected results and shortcomings. It should be emphasized infrastructure (transport, energy, water and telecommunications), functional potential and Disadvantages of settlements. To talk about sustainable tourism development should propose measures and activities specific steps to contribute to the proposed order.

Based on the above to work, in order to realize sustainable development of rural tourism can be drawn the following conclusions: The favourable geographical position and transportation populated municipality of Vrbas; Agriculture as a traditional occupation of the population in rural areas of the municipality (which also contains the largest area of arable land) is a strategic development of the municipality; Eat a well-preserved and protected natural and cultural heritage as its capacity allows the development of tourism activities; Water resources of the municipality, notably the unpolluted waterways and canals Jegricka are the basis for the construction of irrigation systems but also for recreational tourism activities; A multicultural population structure provides a good basis of diversity of experience of potential tourists, mainly because of traditional hospitality.; Lack of infrastructure, which could lead to the construction and improvement of medical services, education through the creation of new majors, cultural and sports facilities, create better living conditions in the rural areas of the municipality; Lack of strategic documents in the field of agriculture, tourism and rural development should be a stimulus to the documents in the following positive expectation prepare, adopt and implement.

\section{Literature}

1. Cobb, C. (1995): Imagery and Indicators, in: McGillivray, A. (Ed.) Accounting for Change, Papers from an international seminar at Toynbee Hall, New Economics Foundation, London.

2. Lješević, M. (2003): Životna sredina sela i nenastanjenih područja, Geografski fakultet, Beograd.

3. Miljković, Lj., Bugarski, D., Bogdanović, Ž., Ćurčić, S., Davidović, R., Tomić, P., Romelić, J., Vujačić, S. (1998): Opština Vrbas, institut za geografiju, PMF, Novi Sad. 
4. Mrkša, M. (2009): Stanje i perspektive razvoja turizma Srednjeg Banata u kontekstu održivog razvoja, doktorska disertacija u rukopisu, Depatman za geografiju, turizam i hotelijerstvo, PMF, Novi Sad.

5. Mrkša, M., Milanović, M. (2012): Održivi razvoj opštine Vrbas, Međunarodni naučni skup „Problemi i izazovi savremene geografske nauke i nastave“, Geografski fakultet, Beograd, pp. 661-669.

6. Mrkša, M., Gajić, T. (2013): Sustainable agriculture as a basic for sustainable environmental development of rural municipality of Vrbas, Ekonomika poljoprivrede, IAE Belgrade, vol. LX, no. 1, pp.153-162.

7. Municipalities in Serbia, publications for selected years (2006-2011), Statistical Office of the Republic of Serbia, Belgrade, Serbia.

8. Plavša, J. (2007): Sportski turizam (skripta), Departman za geografiju, turizam i hotelijerstvo, PMF, Novi Sad.

9. Popović, V., Katić, B., Savić, M. (2011): Ruralni razvoj u Srbiji i lokalne zajednice, Ekonomika poljoprivrede, IAE Belgrade, vol. LVIII, no. 1, pp.33-44.

10.Prentović, R., Kurjački, A., Cvijanović, D. (2012): Hunting in rural areas of Backa, Ekonomika poljoprivrede, IAE Belgrade, vol. LIX, no. 3, pp. 385-400.

11. Radulović, J., Krtolica, S., Bošnjak, M., Simić, J., Spariosu, T., Pantović, M., Pavković, M., Krunić Lazić, M. (1997): Koncept održivog razvoja, Savezno ministarstvo za razvoj, nauku i životnu sredinu, Beograd.

12. Stojanović, Ž., Manić, E. (2009): Održivi ruralni razvoj i prekogranična saradnja, Glasnik SGD, Beograd, vol. LXXXIX, no. 2, pp. 43-64.

13. Zakon o zaštiti životne sredine, Službeni glasnik Republike Srbije, br. 36/09. 


\title{
MOGUĆNOSTI ODRŽIVOG RAZVOJA RURALNOG TURIZMA U OPŠTINI VRBAS
}

\author{
Milutin Mrkšă ${ }^{4}$, Tamara Gajič ${ }^{5}$
}

Rezime

Ruralni turizma se vezuje za ruralna područja. Ruralni turizam podrazumeva sve turističke aktivnosti koje se odvijaju u ruralnim područjima ali i turističke usluge koje se pružaju u istima. Zbog toga je u cilju razvoja ruralnog turizma potrebno je uključivanje lokalnog stanovništva, očuvanje životne sredine u turističkim mestima i stvaranje uslova za ostvarivanje ekonomske dobiti. Sve navedenoi govori da je se ovakav pristup može okarakterisati kao održivi razvoj ruralnog turizma. U radu su na primeru pštine Vrbas predstavljeni potencijali i nedostaci za održivi razvoj ruralnog turizma, ali i predložene konkretne mere.

Ključne reči: Ruralni turizam, životna sredina, održivi razvoj.

4 Dr Milutin M. Mrkša, predavač, Visoka poslovna škola strukovnih studija, Vladimira Perića Valtera 4, 21000 Novi Sad, Srbija, Telefon: +381 63295 711, E-mail: mmrksa@gmail.com

5 Dr Tamara Gajić, Profesor strukovnih studija, Visoka poslovna škola strukovnih studija, Vladimira Perića Valtera 4, 21000 Novi Sad, Srbija, Telefon: +381 2148540 16, E-mail: gajictamara@yahoo.com

EP 2014 (61) 1 (163-175) 
